\title{
HOW POLICIES BECOME CONTESTED: A SPIRAL OF IMAGINATION AND EVIDENCE IN A LARGE INFRASTRUCTURE PROJECT
}

\author{
EVA WOLF \& WOUTER VAN DOOREN ${ }^{1}$
}

\section{ABSTRACT}

This article investigates how framing processes lead to polarization in the public debate on a large infrastructure project. Drawing on an analysis of newspaper articles about the Oosterweelconnection in Antwerp (Belgium), it concludes that framing through imaginative appeals and framing through evidence mutually reinforce each other in a spiralling pattern. When evidence backs up appeals to the imagination, such as when facts back up metaphors, these appeals are endowed with authority and hence legitimacy. While this strengthens appeals that have been "proven" to be true, it also makes actors backing these appeals increasingly frustrated with other parties that still refuse to accept them. Because of their frustration, the former are spurred to launch new imaginative appeals conveying their anger and to seek new evidence to substantiate these new appeals. Over time, as parties in a conflict grapple with evidence and imagination, their tolerance for ambiguity decreases and the debate polarizes.

\section{REFERENCE}

Wolf, E.E.A. and Van Dooren, W. (2017) How Policies Become Contested: A Spiral of Imagination and Evidence in a Large Infrastructure Project. Policy Sciences. Forthcoming.

${ }^{1}$ Both Research Group Public Administration \& Management, Department of Political Science, University of Antwerp, Belgium 


\section{CONTENTS}

1 Introduction 2

2 Framing through imagination and evidence 4

2.1 The framing activity . . . . . . . . . . 4

2.2 Imaginative framing $\ldots \ldots \ldots \ldots \ldots$

2.3 Framing through evidence ............ 6

2.4 Imagination and evidence in the institutions of spatial planning ................... 6

3 Case description: A short history of the Oosterweelconnection 7

4 Methods 10

5 Imaginative framing and framing through evidence in Oosterweel $\quad$ II

5.1 2005: Sickness, scars, and claimed expertise ....... II

5.2 2009: Losing patience but claiming reason . . . . . 13

5.3 2014: Imagining together? . . . . . . . . . . . . 16

6 Framing dynamics: How imagination and evidence reinforce each other 18

6.1 From imagination to evidence and back again ..... 18

6.2 How imagination and evidence reinforce each other. . 20

6.3 Polarization of the debate ........... 22

7 Discussion and conclusion 23

8 References 24

\section{INTRODUCTION}

Few policy issues are able to cause the broad and intense civil unrest that infrastructure projects can. Whether the issue is the construction of a train station (Durnova, 2013), the enlargement of an airport (Michel J. G. van Eeten, 2001), or a railway development project (Novy \& Peters, 2012), controversies over infrastructure are able to engage many people - and at a deep level. An attempt to implement an infrastructure project can therefore trigger years of controversy and negotiation, resulting in a public discourse that is only more divided than ever. This article presents an example of such an entrenched policy conflict (namely the 'Oosterweelconnection' case) which we use to demonstrate how the interaction between imaginative framing and framing through evidence contributes to the polarization of meaning in the public debate.

The Oosterweelconnection is a planned highway that would connect two hitherto unconnected parts of the Antwerp (Belgium) ring road. The Belgian government first developed plans for the project in 1995. Action groups started to oppose these plans in 2005. While this opposition started small, it gained traction over the years. In 2009, the Oosterweelconnection project was voted down in a local referendum. 
In the meantime, both action groups and the government proposed various alternatives for dealing with issues relating to traffic congestion, health, and quality of life, which all actors at least discursively acknowledged as important. At present, a revised project (which is estimated to cost EUR 3 billion) is still in a planning phase and remains highly contested. It is not clear why this policy controversy remains. Why is it that the meanings attached to the same construction project have not eventually converged, despite all of the energy devoted by the parties involved in it to moving beyond conflict?

One potential reason is the presence of different 'frames' (F. Fischer, 2003; Hisschemöller \& Hoppe, 1995: Schön \& Rein, 1994; Stone, 2002; Wagenaar \& Hajer, 2003). When people attach divergent meanings to a situation, they frame it differently, without this difference being overtly apparent. Frames structure communication on an issue, but they are seldom explicitly addressed. One could say that, in the case of policy conflicts such as over the Oosterweelconnection, different meanings covertly underlie the public debate. As long as they are not explicitly addressed, the conflict endures. However, this article attempts to identify how meanings become polarized in the first place. How do actors in a public debate come to see and express the same situation differently over time? We study the mechanisms of conflict development by focusing on the dynamics of framing (van Hulst \& Yanow, 2014). We concentrate on two dynamics: imaginative framing (which entails appealing to the public?s imagination by producing symbolic language) and framing through evidence (which involves appealing to the rationality of one?s vision by producing facts).

The structure of this article is as follows. The first section discusses the two conceptualizations of framing noted above; thereafter we provide a short history of the Oosterweel conflict and present our methods. After discussing the empirical results of our analysis, we then present our main argument. We assert that to gain an advantage in a public debate, actors involved in an infrastructure policy conflict alternate between imaginative framing and framing through evidence. These ways of framing seem to reinforce each other: imaginative appeals spur the production of evidence to claim legitimacy, but this evidence fuels anger when policy contenders do not accept alleged 'truths'; the result is then new imaginative appeals. The debate will polarize over time as each party further develops its own vision of the contested issue and their tolerance for ambiguity decreases. 


\subsection{The framing activity}

The concept of framing first appears in the work of Bateson, who uses it to denote the 'metacommunication' (Bateson, 1955/1987, p. 185; van Hulst \& Yanow, 2014, p. 3) between monkeys that signals whether behaviour is playing or fighting. To the untrained observer, these activities may look similar; however, Bateson reasoned that monkeys somehow frame their actions such that other monkeys can differentiate between them. The concept of framing was later embraced in the field of social psychology, where it inspired scholars from social movement studies (Goffman, 1986; Snow, Rochford, Worden, \& Benford, 1986), dispute resolution studies (A. Dewulf et al., 2009; Gray, 2003), and communication studies (Entman, 1993; Vliegenthart \& van Zoonen, 2011). The concept also became popular in the field of public policy analysis. As scholars began to study framing by humans, they increasingly focused on how actors use language to represent reality. They argued that actors can influence how a situation is interpreted by highlighting specific aspects of that situation while downplaying others; this is how actors frame a situation when talking or writing about it. The same situation can thus be framed in multiple - and possibly conflicting - ways. Despite a common commitment to studying framing through language, however, scholars from different (sub)disciplines engaged with the concept of framing in various ways $^{1}$. We follow the framing approach promoted in public policy literature, as introduced by Rein and Schön (1996; 1994; see also van Hulst \& Yanow (2014)). This approach:

(...) treats frames as strong and generic narratives that guide both analysis and action in practical situations. Such narratives are diagnostic/prescriptive stories that tell, within a given issue terrain, what needs fixing and how it might be fixed. (Rein \& Schön, 1996, p. 89)

The literature describes many cases in which frames are at the heart of policy-making conflicts (e.g., Art Dewulf, Craps, \& Dercon, 2004; Gray, 2003; Hisschemöller \& Hoppe, 1995; Laws \& Rein, 2003; Schon \& Rein, 1994; M.J.G van Eeten, 1999). For instance, Lieshout, Dewulf, Aarts, and Termeer (2011) analyse the debate on so-called 'mega-farms' ${ }^{2}$; in doing so, they show that controversy developed because actors used different scales (namely local, national, and global) as their points of departure when making sense of this phenomenon.

1 For a more elaborate history of the framing concept, see: van Hulst and Yanow (2014)

2 Mega-farms are very large scale farms for intensive animal husbandry 
As long as such scale frames remain implicit, as they did in the case of mega-farms, conflict endures and remains intractable.

Nevertheless, frames do not materialize on their own. As they are constructed by people, the frames change over time as actors interpret new events. Yanow and van Hulst (2014) have recently argued that this dynamic view of framing remains underexplored in the literature. The current paper sets out to analyse how actors discursively construct perspectives on policy issues over time and thus in effect develop different ways of seeing. We focus on two framing dynamics that are often at play in the planning of large infrastructure projects: appeals to the public?s imagination and appeals to evidence as produced by research.

\subsection{Imaginative framing}

Spatial policy-making, concerned as it is with shaping what is not yet there, relies heavily on its ability to communicate visions of the future (M. Van Eeten \& Roe, 2000; Healey, 2007; Throgmorton, 2003). These visions are meant to shape our imagination by telling us stories of how the current use of the spaces we live and travel in falls short and could be improved. While such transformations may rely on technological and architectural operations that we do not comprehend, we should still be able to grasp the end result (which must be convincing). Spatial visions, which depend on our ability to imagine, are transmitted in various ways. Visual representations (such as sketches, movies, and models) are obviously important; however, the language that policy-makers use to communicate with the public also plays a major role.

Language can move people by appealing to their imagination. It can make them excited about the construction of, say, a bridge, but it can also fail completely in doing so and result in either indifference or opposition. As Gusfield notes (1981, p. 7), 'what we cannot imagine we cannot desire'. This does not imply that the way in which something is communicated necessarily determines our reactions in some deterministic way, but language certainly shapes how we feel about issues. Edelman (1977) has highlighted how political language can 'both arouse and assuage anxiety' (p. 4) through the pictures that policy-makers paint of social problems and their solutions. Policymakers can make people care about a situation by arousing anxiety. Thereafter they can present and gain public support for a specific policy that they are presenting as a solution to the threat. Whether a threat is really as significant as is being conveyed does not necessarily have a bearing on the public's anxiety. An example from our case (which is later addressed in more detail) is the description of congestion as a 'traffic infarct': a lethal and sudden event that is damaging the entire Belgian economy. This language creates a sense of 
anxiousness while simultaneously presenting the decision to build new infrastructure as logical (and even necessary). Recent work in the field of policy analysis has highlighted the importance of harnessing the public's emotions as a discursive practice in policy conflicts (Durnova, 2013; Gottweis, 2007; Verhoeven \& Duyvendak, 2015). Appealing to emotions via symbolic language that taps into people's ability to reimagine their future is what we refer to as 'imaginative framing'.

\subsection{Framing through evidence}

Along with visions that appeal to the imagination, appeals to evidence are also omnipresent in spatial policy-making. Instead of stressing the role of imagination, appeals to evidence present policymaking as a rational process of balancing evidence and interests (Throgmorton, 2003). Even though it has been demonstrated that policymaking is not a linear-rational process (F. Fischer, 2003; Stone, 2002; Wagenaar \& Hajer, 2003), many administrative entities in Western democracies today claim to operate in 'evidence-based' ways. The desire for more evidence is not necessarily a bad thing, as evidence can provide means to both judge the viability of policy proposals and counter arbitrary decision-making. However, evidence can also be used for political ends: by asserting that they are acting rationally, policy-makers can claim legitimacy. In infrastructure projects, citizens who resist these projects are often given the NIMBY ('not in my backyard') label by policy-makers. This label presents their claims as fuelled by selfish emotions rather than by sound evidence. The claim that NIMBYs are selfish and irrational presents policy-making as a linear process that is wrongfully impeded by local interests (Burningham, 2000; McAvoy, 1998; Wolsink, 2000).

Appeals to evidence are not devoid of emotion, as numbers and scientific studies can indeed arouse anxiety in the same way as words (Stone, 2002). Nonetheless, emotions are often denied legitimacy as soon as the language of evidence is used. Wielding the authority associated with scientific research, evidence can transform what was once an imaginative vision into an apparent truth, while simultaneously delegitimizing claims that cannot provide such evidence. Appealing to the rationality of one?s vision via language that provides evidence for policy positions is what we refer to as 'framing through evidence'.

\subsection{Imagination and evidence in the institutions of spatial planning}

Meanings do not float freely. They are instead constructed by actors who are institutionally embedded (Campbell, 1998; Hajer, 2005; Schmidt, 2008). Both the re-imagination of space and the interpretation of evidence are nested in Western spatial planning institutions. 
Firstly, as to the re-imagination of space, the practice of spatial planning is by definition deeply concerned with the activity of making plans. As various authors have argued, the making of spatial plans can best be viewed as an activity of re-imagining space and subsequently communicating the results through stories and images (Healey, 2007; Throgmorton, 2003; van Dijk, 2011). Spatial plans also wield power (Flyvbjerg, 2004), as the imaginative stories that they communicate can shape how the public sees what spaces are and should be. Planners thus attempt to influence how people view space through the power-laden act of making plans. Even if the original plans are resisted by the public or result in counter-plans, they define the terms of the conversation. Secondly, as to the production and interpretation of evidence, we have already argued that the institutions of policy-making are often geared towards making policy that is 'evidence based'. As a result, governmental procedures aim at filtering out ideas that cannot satisfy the same burden of proof as others. For example, the need to conduct an environmental impact assessment (EIA) structures spatial policy-making, given that a policy must comply with its terms in order to move forward in the planning process.

In the process of spatial planning, we can thus recognize practices that are intended to both move the public through imaginative appeals and appear rational and wholly un-emotional. Although an increasing body of literature explains how evidence is created in policymaking (Broto, 2013; Frank Fischer, 2000; Moran \& Rau, 2014; Pellizzoni, 2011); and although studies clarify that evidence does not 'speak for itself' (Wesselink, Colebatch, \& Pearce, 2014, p. 341) and instead interacts with the context of policy-making (Boswell, 2014; Nedlund \& Garpenby, 2014; van Herzele \& Aarts, 2013), few deal explicitly with how evidence interacts with other forms of meaning-making. Moreover, although the literature acknowledges that the institutions of spatial planning are concerned with constructing convincing stories about spaces (Healey, 2007; Throgmorton, 2003; van Dijk, 2011), to our knowledge researchers have not yet investigated how appeals to imagination and evidence interact to make stories more or less convincing. This article analyses how imaginative framing and framing through evidence interact over time to create the (various) perspectives that actors have on a spatial policy intervention.

\section{CASE DESCRIPTION: A SHORT HISTORY OF THE OOSTERWEELCONNECTION}

To understand the context of the Oosterweelconnection case, it is first important to know that the Antwerp region has long dealt with traffic congestion. Many feel that the proximity of the Antwerp ring to the city is responsible for this problem. Although governmental agen- 
cies originally envisaged two ring roads (i.e. a smaller inner ring for local traffic and a larger outer ring for through traffic), in the 1960s they eventually chose to build only the smaller inner-city option. Although this ring was meant for local use, it soon became one of Europe?s busiest motorways. Moreover, it was never an actual 'ring'; it was instead more of a semi-circle, which forced traffic to drive right through Antwerp without being able to bypass it.

In 1995, the Flemish road agency ${ }^{3}$ made the construction of a new highway for improving the flow of traffic on the ring road a priority (Verelst, 2009a). In the following years, the government located the trajectory for the new highway close to the city in the Oosterweel area. They therefore dubbed the project the Oosterweelconnection, or 'Oosterweel' for short. The proposed infrastructure consisted of a tunnel under the Scheldt River and an overpass over largely nonoperational docks close to the inner city, thus linking two hitherto unconnected parts of the ring road. The Flemish government presented a scale model of the Oosterweelconnection to political actors from both the Flemish parliament and the Antwerp city council in 2005, and public debate began not long thereafter.

The scale model revealed Oosterweel?s possible impact on Antwerp's city centre. In response, the municipality of Antwerp ordered additional research into the possibility of replacing the overpass with a tunnel. However, when it turned out that a tunnel would be more expensive, the municipal council backed down and began speaking in favour of constructing the Oosterweelconnection as originally planned. A few months later, however, an action group called 'Straten-Generaal' organized a press conference during which they seriously scrutinized Oosterweel's utility. Using much the same argumentation as the city had before, they asserted that the highway would halt urban development due to its proximity to the city centre. Straten-Generaal proposed an alternative trajectory further from town. Claiming that years of research had already proven the superiority of the Oosterweelconnection, the Flemish government was undeterred and continued moving the planning processes forward.

In 2008, the 'Ademloos' (literally, 'Breathless') action group joined the growing civic opposition to the Oosterweelconnection. Ademloos focused on the danger of fine particles in cars' exhaust fumes, arguing that the higher number of cars that would be brought into the city would increase air pollution. The pressure on the Flemish government to give in to the various action groups' pleas for additional research into other trajectories mounted, and that summer it commissioned a 'final' independent study from the Arup/Sum engineering

3 In Belgium, spatial planning is not governed on a federal level, but rather on a regional level by the separate regional governments of Flanders, Walloon, and Brussels. 
company. In the meantime, Ademloos began collecting signatures to call for a municipal referendum on the Oosterweelconnection.

The next year (2009) saw both the presentation of the Arup/Sum study and the Antwerp municipal referendum. The study concluded that no existing plan adequately balanced costs and benefits and instead proposed a new trajectory that strongly resembled the option favoured by action groups. On 18 October, the Antwerp public voted the Oosterweelconnection down by $59.24 \%$. The results were deemed to be legitimate given that $35 \%$ of the city?s residents had voted (a threshold of $10 \%$ needed to be met). Nonetheless, the referendum was not binding; in legal terms, it merely advised the city on how to judge the existing planning permit for the Oosterweelconnection. Those in favour of the project had stressed this non-binding nature all along, also questioning the referendum?s legitimacy. They stressed that only a fraction of municipal residents had voted, and that the Oosterweelconnection concerned more than just the people living in Antwerp. Although the city advised against the planning permit, the Oosterweelconnection project was eventually not cancelled; instead, a decision was taken to replace the much-contested overpass with a tunnel. The Flemish government presented the revision as a compromise, but the action groups objected and claimed that they had always protested the trajectory (and not the overpass as such). The alterations to the proposal forced the government to redo its planning processes, which included conducting a new EIA. In the meantime, the action groups continued to protest.

In 2014, the controversy continued with little change in the discussion. In February, the results of the new EIA yet again led to a conflict over how to interpret the results. In the lead-up to the Flemish elections that year, however, the debate started to shift. A new action group, 'Ringland', joined the protest. Instead of taking sides on the Oosterweelconnection, Ringland attempted to shift the focus of the discussion. The group argued that before any new infrastructure was built, the current ring road in the inner city should be converted to a tunnel - which would enable the land currently used for the ring road to be reclaimed for urban use (hence the name "Ringland"). Both the proponents and opponents of Oosterweel supported the idea of tunnelling the ring road in some way.

Today, both the government's intention to build the Oosterweelconnection and the idea of tunnelling the ring road remain in place. Those opposing the Oosterweelconnection claim that tunnelling is technically impossible if Oosterweel is realized, while those in favour continue to claim otherwise. 
Figure 1: Articles found on the Oosterweelconnection, 2000-2014

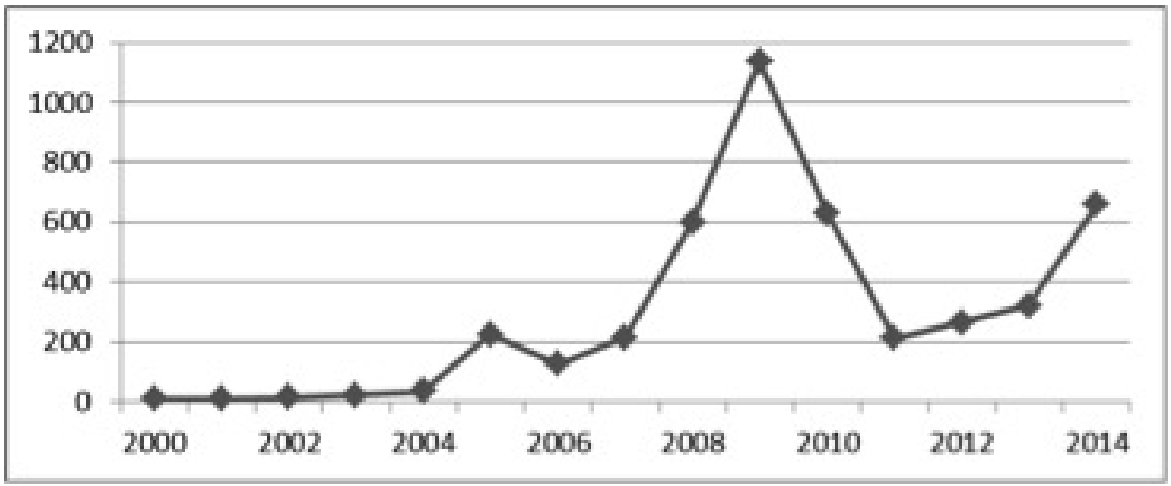

Table 1: Years and months analysed

\begin{tabular}{llll} 
Year & Number of Articles & Month & Key Moments \\
\hline 2005 & 80 & $\begin{array}{l}\text { March } \\
\text { April } \\
\text { October }\end{array}$ & $\begin{array}{l}\text { Presentation of the Oosterweel scale-model } \\
\text { Discussion of the merits of the bridge/tunnel swap } \\
\text { Emergence of the Straten-Generaal action group }\end{array}$ \\
\hline \multirow{2}{*}{2009470} & $\begin{array}{l}\text { March } \\
\text { October }\end{array}$ & $\begin{array}{l}\text { Publication of the results of the independent study } \\
\text { Antwerp municipal referendum on Oosterweel }\end{array}$ \\
\hline 2014 & 189 & February & Release of the EIA; emergence of the Ringland action
\end{tabular}

\section{METHODS}

To analyse the public debate on Oosterweel, we studied media articles pertaining to the Oosterweelconnection from 2005, 2009, and 2014. These years were chosen as they represent the peaks in media attention and are hence assumed to have been important years for the case. The peaks were identified by searching for articles containing the word "Oosterweelconnection" in the period from 2000 to 2014 4; Figure 1 depicts the number of articles found for various years.

We analysed multiple years because we were interested in how the framings have developed over time. For each year, we first scanned through the article titles; thereafter we chose several months in each year to analyse in greater depth. These months were tied to key moments and scored highest in terms of media attention. We analysed a total of 739 articles; Table I presents the number of articles, months analysed, and key moments for the three years considered.

We inductively coded the peak months for each year for symbolic language use and evidence claims utilizing the Nvivo software program. In this coding, we focussed on identifying discursive elements in the argumentation for and against Oosterweel (rather than on trac-

4 We used the online database GoPress, which contains all Flemish newspapers. We included the following newspapers in the search: De Standaard; De Morgen; De Gazet van Antwerpen; Het Laatste Nieuws; De Tijd; Het Nieuwsblad; Metro; and Het Belang van Limburg. These eight represent all Flemish subscription newspapers, along with a free newspaper (Metro) with a wide readership. The Flemish edition of each newspaper was used. If only regional editions existed, we chose the Antwerp edition, as Antwerp is where the Oosterweelconnection is planned. 
ing the position of individual actors). Symbolic language consisted mostly of metaphors, which reveal the way in which one thing is understood in terms of another (Lakoff \& Johnson, 1980) and thus attuned us to how the actors imaginatively constructed specific images of Oosterweel. For example, by likening Oosterweel to a 'scar' in the 'urban tissue' of Antwerp, actors revealed that they understood Antwerp as an organism and Oosterweel as an alien element. Actors sometimes also used symbolic language other than metaphors; examples include proverbs and the comparison of Oosterweel to other infrastructure projects or to events in the distant past. We coded for both symbolic language relating to the Oosterweelconnection and symbolic language pertaining to the policy-making process. Evidence claims consisted of presented facts that supported specific interpretations of the Oosterweelconnection; these facts often arose from reports, but not always. An example would be using numbers (as in ' $x$ ' people support the Oosterweelconnection) to prove the support or lack thereof for Oosterweel. We also divided the various symbolic and knowledge claims into 43 themes, such as health, environment, and spatial impact.

After a first round of coding, we regrouped smaller codes under larger labels. In this second coding round, we also recoded pieces of text that in retrospect fit better under different labels. This coding scheme enabled us to distinguish between imaginative framing and framing through evidence. The former relied on the use of symbolic language to reimagine Oosterweel, while the latter depended on providing evidence to claim facticity. This evidence consisted of numbers, references to specific research, claims made by scientific experts, and references to specific parts of codified law.

\section{IMAGINATIVE FRAMING AND FRAMING THROUGH EVIDENCE IN OOSTERWEEL}

In this section we describe the main imaginative appeals and appeals to evidence present in the Oosterweel debate in 2005, 2009, and 2014. The metaphors we cite are not our own, but rather the metaphors used in the debate.

\subsection{5: Sickness, scars, and claimed expertise}

The public debate over Oosterweel started in 2005. The first media peak we studied followed the presentation of the scale model and the municipal decision to order additional research on the project, while the second followed the founding of Straten-Generaal and this group's subsequent engagement in the public debate. 


\subsubsection{Imaginative framing}

The traffic infarct: In 2005, Oosterweel was predominantly depicted as a project to solve traffic congestion problems. This perspective was put forward by governmental advocates (both administrative actors and political actors from the Flemish coalition parties), but it was also adopted by the news media more generally. An especially pervasive metaphor reflected Belgium suffering from a traffic infarct, for which Oosterweel was said to be the cure. The medical metaphors for congestion symbolized an organic entity (Belgium) with a sick 'heart' (Antwerp) - note that the harbour of Antwerp represents 149,714 direct and indirect jobs (2016: Feiten en cijfers, 2016) which is why inter alia actors could depict it as the heart of Belgium. In line with this metaphor of sickness, the governor of the Antwerp province replied as follows to the municipality?s decision to order additional research:

It endangers the whole Master Plan [the Oosterweelconnection is embedded in a broader plan] to cure the traffic infarct. This is a historical opportunity for Antwerp, but everyone is suddenly speaking ill (as cited in "Stad speelt met vuur 2005", p. 20).

This quotation shows how the traffic infarct metaphor worked to create a sense of urgency: swift action is necessary, as disaster can strike any moment.

The tissue of the city: Another important metaphor involved Oosterweel damaging the city?s tissue. Oosterweel would be a "scar", because it would 'slice' the 'city-tissue' into parts; in doing so it would hinder opportunities for urban development. This metaphor was first used in the media around the time the municipality decided to call for additional research into the possibility of building a tunnel. A few months later, Straten-Generaal re-used it. The group also voiced disappointment over the municipal decision to support Oosterweel after the additional costs of a tunnel had been revealed. Straten-Generaal portrayed this decision as an example of short-sighted policy-making, as illustrated by the following comparison that the group made:

At the end of the nineteenth century, wharfs of the Scheldt in the city of Antwerp were straightened to safeguard the ambitions of the harbor. Over a thousand houses were destroyed. Not long thereafter the harbor made a definitive move to the north of the city. But the medieval heart of the city had disappeared. A similar lack of vision characterizes the planned Oosterweel overpass. (Claeys, 2005, p. 36)

This re-characterized the city of Antwerp as a deeply historic place, rather than as being 'sick'. By referring to a bygone past, StratenGeneraal likened the current affair to previous urban planning efforts. 
The comparison alluded to the very real consequences any decision now would have on the long-term future of Antwerp, and as such lent urgency to the need to reconsider Oosterweel.

\subsubsection{Framing through evidence}

Research and expertise: From the start, the governmental advocates of Oosterweel claimed that they were acting rationally while the protesters were not. The following quotation from an actor from the governmental agency responsible for executing Oosterweel (BAM) clearly illustrates this assertion:

It [the trajectory proposed by Straten-Generaal] was investigated and rejected a long time ago. People sometimes forget that we have been working on this for seven to eight years already (as cited in Falter, 2005, p. 13).

Alongside various metaphors, the government?s alleged possession of superior knowledge that was built on prior research thus played a role in setting the terms of the Oosterweel conversation from the very start of the debate.

\subsection{9: Losing patience but claiming reason}

The first peak of media attention in 2009 followed the publication of the Arup/Sum study results, while the second followed the period surrounding the October municipal referendum on the Oosterweelconnection. It is also important to keep in mind that the Ademloos action group (whose main claim was that Oosterweel would damage the health of Antwerp residents) had joined the debate by this point.

\subsubsection{Imaginative framing}

Out of time: A very important symbol in the debate of 2009 was that of time running out. While connected to the traffic infarct metaphor (as time was running out due inter alia to the alleged infarct), it stressed that the delay and related costs were problems in and of themselves. The metaphor of time running out was pervasive in the debate following the publication of the Arup/Sum study and was primarily used by both administrative actors and political actors from Flemish coalition parties. These groups claimed that the results showed the need to find a solution for traffic congestion quickly, which they asserted meant going ahead with the Oosterweelconnection (given that the Oosterweel option would need less study and procedural work than alternative options). Moreover, they argued that building Oosterweel quickly was all the more necessary because of the economic crisis in Belgium, as they claimed that large infrastructure projects would boost the economy. 
Standstill: Some politicians from Flemish coalition parties plus a few journalists and politicians from parties generally hesitant towards referenda contested the legitimacy of the Oosterweel referendum. They claimed that a municipal referendum was uncalled for seeing as the Oosterweelconnection was not just an issue for Antwerp, but rather for Belgium at large. In other words, Antwerp was acting selfishly by not taking the larger public interest of battling congestion quickly into consideration. Their reasoning was similar to the NIMBY allegation discussed previously, albeit applied to a whole city rather than to individuals. The argument was that taking the referendum too seriously could set a precedent for cities all over Flanders to block projects that were necessary for Flanders and Belgium at large (including refugee centres and airport expansions), which would ultimately result in a complete construction and development standstill.

Poison: By 2009, the opposition to the Oosterweelconnection had come to resist Oosterweel not only due to its alleged spatial impacts, but also as a result of its alleged effects on the respiratory health of Antwerp residents. Poison was used as a metaphor for the latter. Protesters characterized cars as poisonous - even deadly - to those living in close proximity to roads due to the fine particles in the exhaust fumes. The image of cars as poisonous was also connected to the city?s industrial history. In the past, residents had been exposed to various chemicals that were generally claimed to be innocuous at the time but later turned out to cause serious illnesses. As one protester interviewed by a newspaper illustratively explained:

I remember that, as a teacher, I took my students to the sea 30 years ago. For one week, as a treatment. Because the lungs of all were poisoned by the Metallurgie [a factory in the neighborhood] (...) The Lange Wapper [name given to the Oosterweel overpass] evokes painful memories, I see very strong parallels. Not lead this time, but fine particles. (As cited in Verelst, 2009b, p. 26) As this quotation demonstrates, the image of Oosterweel as poisonous captured the imagination of many and was a powerful image in the public debate in 2009. Nonetheless, this did not mean that protesters stopped using metaphors related to Oosterweel damaging the urban tissue; the project?s alleged damage was simply expanded to include both the damage done to the city itself and the harm caused to its citizens.

Smokescreen: Finally, action groups not only took on the infrastructure as such; they also voiced anger over the way in which the government had handled the decision-making process. They claimed that the government had repeatedly responded to criticisms raised against the Oosterweelconnection in a deceitful way. For example by 
lying about European rules and about safety regulations. More importantly, they asserted that the mere fact that the government had ordered an independent review (i.e. the Arup/Sum study) but then resisted its conclusions proved that it was not taking alternatives to Oosterweel seriously. Action groups claimed that the government was using research as a mere smokescreen, both at the moment and in the past. As a member of Straten-Generaal noted in an interview:

It [the 2005 municipal study] was completely adapted to BAM. A worthless piece of work. Nevertheless, the city of Antwerp has used that rubbish for years as a smokescreen to not have to act against the Oosterweelconnection. (As cited in De Baere, 2009, p. 26)

\subsubsection{Framing through evidence}

The unreasonable other In 2009, like in 2005, metaphors mobilized by actors were coupled with evidence to substantiate them. In the public debate of 2009, the very existence of something other than 'pure' rationality in the discussion over Oosterweel was denounced. Shaming others as being emotional rather than rational was used to depict the other in a bad light. Thus both sides claimed that they were acting rationally while the other side was not. Consider the following quotation from a political actor from the BAM?s governing board:

At first it was about fine particles, then about noise, then about residential areas and schools, then about the junction at Schijnpoort and, lastly, about the fact that the ring is too close to the city? Or: how feelings of anxiety from the people of Antwerp have been abused. (Demeester-De meyer, 2009, p. 26)

It is thus unsurprising that assorted actors stepped up the production of various kinds of facts in 2009, which they then used to delegitimize those holding different positions towards Oosterweel. We first saw this with regard to facts concerning the poisonous nature of fine particles and the number of illnesses and deaths these particles were believed to cause. These were brought forward by protesters and publicly confirmed by medical experts. In the meantime, a group of experts on tunnel safety spoke out on behalf of those supporting the Oosterweel overpass. While the Arup/Sum study claimed that the tunnel option would be perfectly safe, both administrative actors and political actors from the Flemish coalition cited the tunnel experts who had stated that alternatives to Oosterweel were not feasible. Finally, 2009 was a year of arguments using numbers and arguments about numbers The most striking debate over numbers erupted after the referendum. While Oosterweel opponents interpreted the outcome as a clear vote against the connection, some in favour of it 
thought differently. In an interview just after the referendum, the chairman of BAM's board reasoned:

"You have to put the outcome in the right context. A turnout of 35 per cent is particularly low, especially for a megaproject such as the Oosterweelconnection" (as cited in Verelst, 2009c, p. 2). He further noted that: "Besides, $40 \%$ voted yes. That must mean something. There is support for our project too. It comes down to a difference of just over 20,00o people, in a city of half a million residents" (as cited in Verelst, 2009c, p. 2).

Clearly, the same numbers could be mobilized in very different ways.

\section{$5 \cdot 3$ 2014: Imagining together?}

The Oosterweel debate was still on-going in 2014. The results of the new EIA were presented in February, which is the first media peak we studied. With the Flemish elections approaching, the debate in May (the second media peak we analysed) then centred on the Ringland action group?s proposition to tunnel the existing ring road before building new infrastructure.

\subsubsection{Imaginative framing}

Moving forward: In February 2014, the media seemed tired of the never-ending discussion on Oosterweel and would rather end it. When the EIA stated that the Oosterweelconnection would be the most beneficial trajectory for improving mobility, many media articles thus applauded the possible conclusion. Administrative actors and political actors from Flemish coalition parties echoed this sentiment when they declared the Oosterweelconnection the unambiguous winner of the EIA and voiced their desire to move the planning procedure forward with full force. Interestingly, they presented the tedious nature of the continuing process as the main reason to move forward, rather than the imagined prospect of an impending traffic infarct. They stressed that too much time had already been lost to talk and research and that the time had truly come to decide. This image of having to move forward was immediately coupled with the possibility of further - and supposedly unjustified - delay as a consequence of possible actions from Oosterweel opponents, who were literally being asked to stop their protest for the common good.

Bread for the hungry: In 2009, the image of research being used as a smokescreen had depicted the government as deceitful and as hiding its true intentions. This devious image was appealed to again in 2014, when Straten-Generaal and Ademloos claimed that the government wanted to push Oosterweel through at any cost. They cast 
the changes the government had made to the project over the years as nothing more than 'bread for the hungry': minor concessions to appease the public. This image added the notion of the government distorting its actions to the existing notion of the government manipulating research. The action groups claimed that this was true for both the government's post-referendum decision to do away with the overpass and its newly emerging interest in tunnelling parts of the ring road. Protesters asserted that the government was merely paying lip service to the idea of tunnelling in order to harness public support in the upcoming elections, arguing that it made no sense at all to combine Oosterweel with tunnelling. Why bring more cars into the city and then build tunnels, rather than just keeping the cars away from the city to begin with?

Putting a roof on it, the sanitation of the ring: Despite the fact that action groups distrusted governmental intentions, in 2014 the parties shared a desire to literally put a roof on the Antwerp ring road. In other words: transforming the ring road into a tunnel. The metaphor of sanitation captures what the tunnelling of the ring road meant for those both for and against Oosterweel. The metaphor, which refers to the process of keeping places free from dirt by removing waste, was presented as way of doing away with adverse effects of the city's infrastructure. Through tunnelling, cars would be removed from sight and smell so that infrastructure would serve residents as well as cars.

\subsubsection{Framing through evidence}

The EIA as contested evidence: As demonstrated earlier, administrative actors and political actors from coalition parties claimed the EIA as the ultimate evidence of Oosterweel?s superiority and used it as grounds for pushing the planning process forward with full force. This argumentation was further reinforced with a cost-benefit analysis that quantitatively demonstrated the Oosterweelconnection's benefits for the Belgian economy. The reaction of the project's opponents was twofold: they objected to how the EIA treated non-Oosterweel trajectories, but also claimed that even with this flawed treatment their own favoured trajectory was still superior. These groups provided evidence to support the image of governmental deceit in at least two ways. Firstly, they provided evidence for their trajectory being superior in the form of various numbers taken from the EIA; as noted by an actor from Straten-Generaal:

"For those who want to see it, the EIA states the choice clearly: will we go for a few minutes of time gain for traffic or for the improved health of 70,00o people in seven parts of the city?"(as cited in Brillouet, 2014, p. 16).

Secondly, Oosterweel opponents attempted to discredit the validity of the evidence provided in the EIA. They especially criticized 
the EIA for treating the Oosterweel trajectory differently from other trajectories; for example, they claimed that much more elaborate calculations were used for Oosterweel in investigating how different toll options could best be combined with infrastructure to maximize mobility gains.

The possibilities of tunnelling: As mentioned earlier, those both for and against Oosterweel publicly supported the tunnelling project. However, the problem was that various actors had different interpretations of what this tunnelling meant, which resulted in conflicting knowledge claims. Straten-Generaal, Ademloos, and political actors from opposition parties viewed the tunnelling as an alternative to the Oosterweel trajectory and claimed that combining the two not only made no sense but was also technically impossible. In contrast, administrative actors and political actors from coalition parties claimed that the two could indeed be combined; many of them also stated that doing so was a good idea. Each side used its own sources of evidence, which consisted of either specific extracts from the EIA or excerpts from earlier research into possibilities for tunnelling parts of the Antwerp ring road. Meanwhile, the action group Ringland, which had launched the tunnelling idea, refused to speak out for or against Oosterweel and merely pushed the priority of tunnelling. This situation of various actors making opposing factual claims led to much confusion in the newspapers, as well as to back-and-forth accusations of 'lying' between proponents and opponents of Oosterweel.

\section{FRAMING DYNAMICS: HOW IMAGINATION AND EVIDENCE REINFORCE EACH OTHER}

The above discussion of some of the more important appeals to imagination and evidence in the Oosterweel debate presents a rather static description of the framing process. In this section, we discuss how the dynamic interaction between imaginative framing and framing through evidence has contributed to policy contestation. We first elaborate how the public debate on Oosterweel alternated between imagination and evidence, thereafter showing how the two types of framing reinforced each other and thus resulted in a spiralling dynamic. We end the section by discussing the consequences this dynamic has had on the polarization of the public debate.

\subsection{From imagination to evidence and back again}

In the section "Framing through imagination and evidence", we discussed how using symbolic language in policy-making captures the public?s imagination. This is important, because people must be made to care about public issues before they will support policies. In 
the debate over Oosterweel, it is clear that actors repeatedly appealed to the imagination. Symbols such as a traffic infarct, the urban tissue, and a smokescreen are not material, but rather narrative images of what could be. They capture our attention due to their emotional character and the sense of urgency they convey. The image of a traffic infarct clearly appealed to feelings of anxiety and the sense that disaster was impending. The same was true of the images of Oosterweel as damaging the urban tissue and the lungs of current and future generations. In addition, the smokescreen metaphor and the image of protesters creating a standstill highlighted the unjust course of events and added appeals to anger over the policy-making process to the existing anxiety over an insecure future.

However, it has also been illustrated that the emotional and essentially imaginative nature of these appeals was denied legitimacy in the open dialogue. Moreover, actors were eager to deny that emotions played any part whatsoever in their take on Oosterweel. To deny the imaginative nature of their appeals, actors both for and against the project produced many facts to support their positions in the course of the policy-making process. Substantiating their positions in this way enabled them to claim that their stories were representative of the truth, and consequently that other stories - which they labelled as emotional rather than rational - were not.

Importantly, the institutional context influenced both the imaginative appeals and the appeals to evidence that actors produced over the years. Oosterweel was initially conceptualized as primarily a solution to the so-called traffic infarct in Flanders. The traffic infarct was an imaginative vision that had been both developed in the spatial planning process over the course of years and substantiated through research. When the debate began in 2005, governmental actors thus had an edge over protesters given that they had already constructed an imaginative story about Oosterweel and could claim that years of research substantiated the need for new infrastructure. Nevertheless, protesters immediately mobilized an opposing story by using imaginative visions of Antwerp?s past and future. By dubbing Oosterweel a scar in the urban tissue, they could mobilize the public to imagine Oosterweel as alien and undesirable rather than highly urgent. Over time, this more negative story was joined by other hostile visions, such as that Oosterweel was poisonous and its proponents were devious. Protesters also attempted to mobilize evidence to substantiate their perspective on Oosterweel, for example by requesting additional research and rallying the expertise of medical professionals. While governmental actors had stories and evidence that opponents did not at the beginning of the conflict, this imbalance was redressed over time. Protesters succeeded in both getting Oosterweel onto the political agenda and offsetting the governmental actors? initial edge due to the government's embeddedness in the institutions of spatial policy- 
making. Moreover, protesters actively tried to use such institutions to their own benefit, most notably through their request for research (but also inter alia by calling for a municipal referendum). The case illustrates how, as Healey (2007) aptly puts it, "those involved in spatial strategy-making for urban regions may imagine futures, but what evolves through time is continuously escaping their grasp and their power to define in advance" (Healey, 2007, p. 10).

The proponents and opponents of Oosterweel both continued to alternate between imaginative framing and framing through evidence over time, which resulted in an increasingly rich repertoire of imagination and evidence being constructed. For example, the image of a traffic infarct never completely disappeared from the debate and instead became the point of reference for subsequent images; likewise, the research from 2005 still contributed to the image of research being a smokescreen many years later.

\subsection{How imagination and evidence reinforce each other}

As the repertoire of appeals continued to grow, imagination and evidence also reinforced each other; this is why we use the image of a spiral. The arguments for and against Oosterweel not only displayed an alternation between imagination and evidence, but new evidence also inspired new imaginative visions and vice versa. Once Oosterweel opponents had research to back up their metaphors, the fact that Oosterweel supporters would not accept this knowledge seems to have made them angrier, at least discursively, throughout the decision-making process. This led the opponents to creating new symbols - and hence new imaginative visions - to communicate their anger. These visions were in turn substantiated through the production of new evidence, which then inspired new imaginative appeals. This mutually reinforcing cycle of imagination and evidence can be found among both proponents and opponents of Oosterweel.

For Oosterweel proponents, the image of an impending traffic infarct was substantiated in various pieces of research. The fact that, nevertheless, the resistance to Oosterweel remained then triggered these actors to create the image of time running out, as well as the image of reaching a standstill as a consequence of selfish behaviour by opponents. When the EIA allegedly confirmed what the proponents had been saying all along, those in favour of Oosterweel made a strong plea for finally moving forward for the common good. This was coupled with a desire to combine Oosterweel with putting a roof on the existing ring road, which was backed up with claimed expertise on tunnelling. Figure 2 on the following page illustrates how Oosterweel proponents alternated between imagination and evidence. 
Figure 2: The imagination-evidence spiral: Pleading for Oosterweel

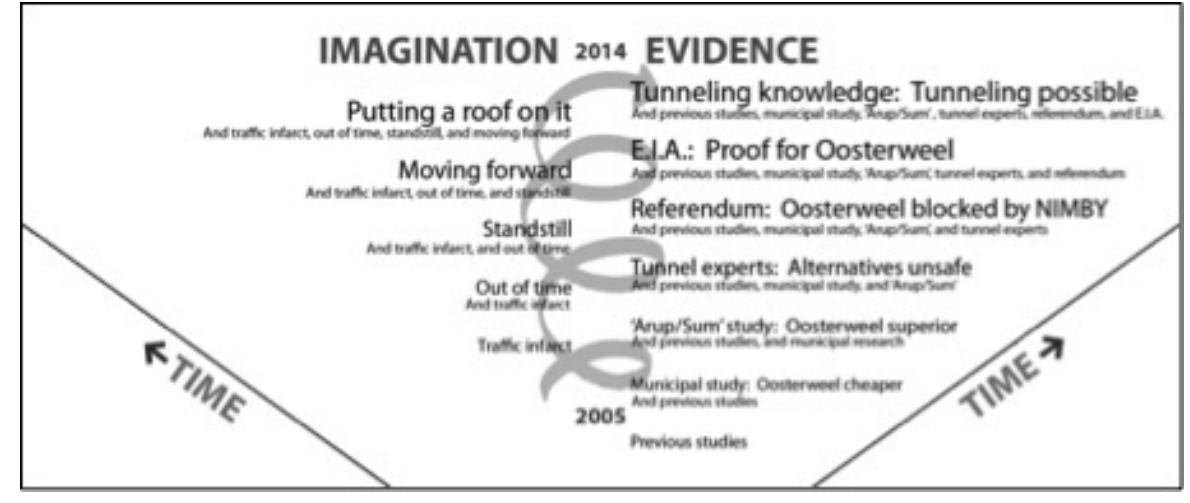

Figure 3: The imagination-evidence spiral: Pleading against Oosterweel

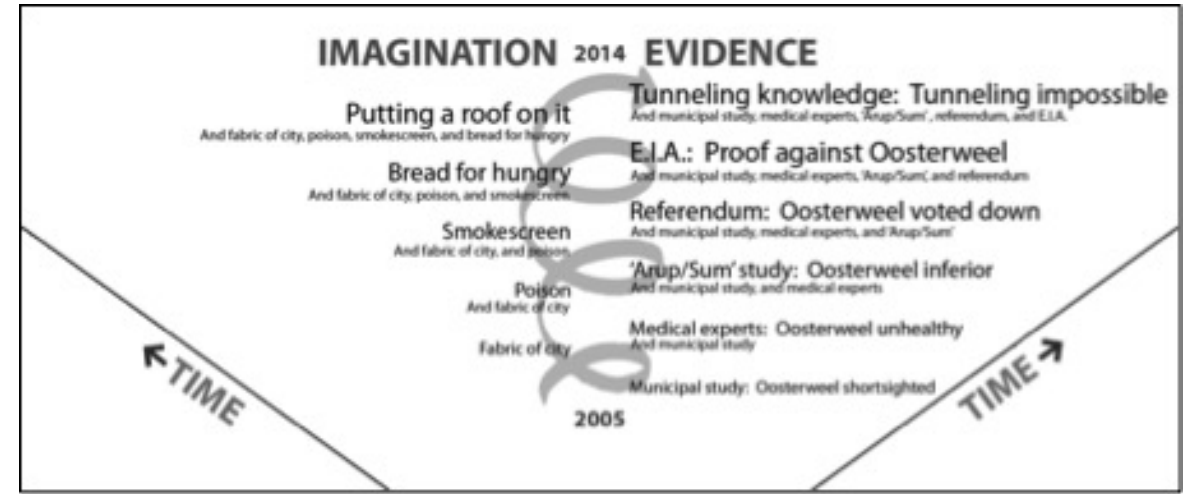

A similar process can be observed for Oosterweel opponents. The metaphors of Oosterweel damaging the city?s tissue and being poisonous were also substantiated over time through various research, while this production of facts simultaneously made protesters angry about not being listened to and hence provided input for the smokescreen metaphor and the bread for the hungry image. In the end, the idea of putting a roof on top of the ring road was embraced by opponents, although it was also presented as technically incompatible with Oosterweel. The very fact that those in favour of Oosterweel claimed that combining the project with a tunnel would be possible was interpreted by Oosterweel opponents as yet another example of governmental deceit. Figure 3 depicts how Oosterweel opponents alternated between imagination and evidence.

When facts back up imaginative appeals, these appeals are endowed with authority and hence legitimacy. While this bolsters appeals that have been 'proven' to be true, it also seems to produce additional frustration with the 'other', a new surge of visions concerning the 'other's' devious nature, and new facts to confirm these bad intentions. 


\subsection{Polarization of the debate}

Thus far we have discussed the dynamics of framing within the discourse of Oosterweel proponents and opponents. However, the mutual reinforcement of imaginative framing and framing through evidence also yields consequences for the interaction between the two sides. As actors alternate between imagination and evidence, they get more deeply entrenched in their own visions and become more frustrated that what is obvious to them is denied by the other group. In the case of Oosterweel, over time both sides of the debate began referring to their opponents in increasingly antagonistic ways in their argumentation, criticizing each other for not accepting manifest 'truths'. In other words, the ambiguous nature of the issue at hand became increasingly less ambiguous in the eyes of those participating in the public debate. Each side continued to amass a growing arsenal of evidence to prove that beyond simply having a different vision of the contested issue, their opponents were in fact lying.

We hence argue that the way in which actors articulated their positions on Oosterweel, namely by alternating between imaginative framing and framing through evidence, contributed to the polarization of the public debate on the project. This polarization was illustrated by the protesters? reactions to the government?s post-referendum decision to do away with the contested overpass but keep the Oosterweel trajectory. While the overpass had been at the heart of the initial Oosterweel conflict, the imaginative framing of Oosterweel as a negative force, which was bolstered by evidence concerning Oosterweel?s impact and the possibilities for alternative trajectories, led protesters to opt for an entirely different trajectory. After the referendum, they became upset when 'merely' the overpass was done away with. The polarization in the debate was also illustrated in the move from what might be called framing merely the 'issue' at hand to framing the 'process' and 'identity' as well (van Hulst \& Yanow, 2014). Over time, and through the alternation between imagination and evidence, the debate expanded from being just about infrastructure to also include decision-making and even how democracy works. In the public discourse both for and against Oosterweel, the portrayal of the other side as acting selfishly and being intent on pushing its own vision through no matter the consequences developed over time.

Of course, this observation does not mean that actors are somehow locked inside this spiral. As we have seen in the Oosterweel case, the idea of tunnelling the ring road reintroduced ambiguity into the debate, which might function as way to 're-frame' (Rein \& Schon, 1993) the different perspectives on the project. Nonetheless, we again saw that although the Oosterweel proponents and opponents used similar language, they clearly did not trust each other. The concept of a spiral thus enables us to better grasp the dynamics behind the curious phenomenon that discursive positions often deepen and grow 
more antagonistic over time in public conflicts, despite the fact that actors put so much energy into resolving the issue at hand. Their very enthusiasm to conclude the discussion through evidence might actually lead to further polarization.

\section{DISCUSSION AND CONCLUSION}

We have analysed how the framing process leads to a polarization of meanings in the public debate on an infrastructure project, with a specific focus on the interaction between imaginative framing and framing through evidence. While imaginative appeals move people emotionally by encouraging them to reimagine better spatial environments, the process of producing evidence denies the imaginative nature of spatial policy-making and often denounces the very presence of emotions in a debate.

The empirical analysis consisted of an in-depth study of newspaper articles about the contested Oosterweelconnection in Antwerp that were published at key moments in 2005, 2009, and 2014. Both proponents and opponents of Oosterweel vied for public support by alternating between imaginative appeals and appeals to evidence, both of which were enabled by the institutionally embedded positions of the actors involved. Due to their institutional embeddedness, governmental actors in favour of Oosterweel initially had an edge in the debate; through years of planning, they had already constructed a persuasive story about the Oosterweelconnection and had the evidence to back that story up. However, protesters succeeded in overcoming this imbalance by reimagining Oosterweel and mobilizing their own evidence. Over time, and by alternating between imagination and evidence, both sides of the debate created an increasingly large repertoire of symbolic images and facts. Moreover, imaginative framing and framing through evidence mutually reinforced each other, which is why we speak of a spiral-like pattern. Imaginative suggestions on the benefits or harms of Oosterweel were substantiated with evidence to prove that the actors? positions were rational. This evidence in turn fuelled anger over the other party?s non-acceptance of the manifest 'truths' and hence inspired new symbols. The public debate thus polarized as each party further developed its own vision of the issue and the mutual tolerance for ambiguity decreased.

This article offers various contributions to the literature. First and foremost, it provides those who are interested in the dynamics of framing (van Hulst \& Yanow, 2014) with a new focus (on imagination and evidence) for analysing how different ways of seeing develop. It hence could help researchers to further develop specific frame types in relation to time. Why do actors over time come to emphasize conflict (Brummans et al., 2008), risk (Elliott, 2003), or scale (Kurtz, 
2003; Lieshout et al., 2011) in their arguments, rather than other dimensions of an issue? This might be due to the imagination and evidence interacting in specific ways to produce these foci. Secondly, for scholars who study evidence-based policy-making (Boswell, 2014; Nedlund \& Garpenby, 2014; Wesselink et al., 2014), our analysis not only confirms that evidence interacts with the context in which it is operationalized, but it also stresses the mutual reinforcement of eevidenced' and 'non-evidenced' meaning-making. Thirdly, for the field of spatial planning (Healey, 2007; Throgmorton, 2003; van Dijk, 2011), our analysis demonstrates how institutionally embedded actors combine imaginative appeals and appeals to evidence in crafting persuasive stories and specifically illustrates how these appeals can interact. The imagination-evidence spiral can also be of interest to scholars who study policy conflicts. For example, this study confirms that in policy conflicts that seem intractable, also referred to in the literature as 'dialogues of the deaf' (M. J. van Eeten, 1999), additional research alone will not help to resolve an issue. Research can even contribute to escalation, as beyond bolstering existing images new research may also fuel additional - and more adverse - meaning-making. Finally, our analysis shows how detrimental it can be not to acknowledge the imaginative side of policy processes, especially when conflicts arise. By denying the very existence of emotions in related debates, the conversation over different ways to imagine space is halted while the production of facts to legitimize each side?s position is triggered which can escalate a conflict rather than bring it to an end.

\section{REFERENCES}

2016: Feiten en cijfers. (2016). Cijferboekje 2016. Retrieved from http://www.portofantwerp.com/nl/

Bateson, G. (1987). A theory of play and fantasy. In G. Bateson (Ed.), Steps to an ecology of mind: Collected essays in anthropology, pshychiatrie, evolution, and epistemology (Original w., pp. 183-198). Northvale: Jason Aronson Inc.

Boswell, J. (2014). 'Hoisted with our own petard': evidence and democratic deliberation on obesity. Policy Sciences, 47(4), 345-365.

Brillouet, W. (2014, February 12). Regering moet kiezen: mobiliteit vs leefbaarheid. Gazet van Antwerpen, p. 16.

Broto, V. C. (2013). Symbolic violence and the politics of environmental pollution science: The case of coal ash pollution in Bosnia and Herzegovina. Antipode, 45(3), 621-640.

Brummans, B. H. J. M., Putnam, L. L., Gray, B., Hanke, R., Lewicki, R. J., \& Wiethoff, C. (2008). Making sense of intractable multiparty conflict: A study of framing in four environmental disputes. Communication Monographs, 75(1), 25-51. 
Burningham, K. (2000). Using the Language of NIMBY: A topic for research, not an activity for researchers. Local Environment, 5(1), $55-67$.

Campbell, J. L. (1998). Institutional Analysis and the Role of Ideas in Political Economy. Theory and Society, 27(3), 377-409.

Claeys, M. (2005, September 7). Schuif de Oosterweelbrug dan noordwaarts. De Standaard, p. 36.

De Baere, M. (2009, March 7). Hoe de Lange Wapper crashte aan een keukentafel in Borgerhout. De Morgen, p. 26.

Demeester-De meyer, W. (2009, October 16). Wivina Demeester vindt dat Oosterweel past bij een ambitieuze stad. De Morgen, p. 26.

Dewulf, A., Craps, M., \& Dercon, G. (2004). How issues get framed and reframed when different communities meet: a multi-level analysis of a collaborative soil conservation initiative in the Ecuadorian Andes. Journal of Community \& Applied Social Psychology, 14(3), 177-192.

Dewulf, A., Gray, B., Putnam, L., Lewicki, R., Aarts, N., Bouwen, R., \& van Woerkum, C. (2009). Disentangling approaches to framing in conflict and negotiation research: A meta-paradigmatic perspective. Human Relations (Vol. 62).

Durnova, A. (2013). A tale of 'fat cats' and 'stupid activists': Contested values, governance and reflexivity in the Brno railway station controversy. Journal of Environmental Policy \& Planning, (October 2013), 1-17.

Edelman, M. (1977). Political language: Words that succeed and policies that fail. New York: Academic press.

Eeten, M. J. G. van. (2001). Recasting intractable issues?: The Wider implications of the Netherlands Civil Aviation Controversy. Journal of Policy Analyis and Managament, 20(3), 391-414.

Eeten, M. Van, \& Roe, E. (2000). When fiction conveys truth and authority. Journal of the American Planning Association, 66(1), 58-67.

Elliott, M. (2003). Risk perception frames in environmental decision making. Environmental Practice, 5(03), 214-222.

Entman, R. M. (1993). Framing: Toward Clarification of a Fractured Paradigm. Journal of Communication, 43(4), 51-58.

Falter, R. (2005, September 24). Diesel over de dokken. De Tijd, p. 13.

Fischer, F. (2000). Citizens, experts, and the environment: The politics of local knowledge. Duke University Press.

Fischer, F. (2003). Reframing public policy: Discursive politics and deliberative practices. New York: Oxford University Press.

Flyvbjerg, B. (2004). Phronetic planning research: theoretical and methodological reflections. Planning Theory \& Practice, 5(3), 283-306.

Goffman, E. (1986). Frame analysis: An essay on the organization of experience. Boston: Northeastern University Press. 
Gottweis, H. (ed. . (2007). Rhetoric in policy making: Between logos, ethos, and pathos. In F. Fischer, G. J. Miller, \& M. S. Sidney (Eds.), Handbook of public policy analysis: theory, politics, and methods (pp. 237-250). Boca Raton, FL: CRC Press.

Gray, B. (2003). Framing of environmental disputes. In R. J. Lewicki, B. Gray, \& M. Elliott (Eds.), Making sense of intractable environmental conflicts (pp. 11-34). Washington: Island Press.

Gusfield, J. R. (1981). The culture of public problems: Drinkingdriving and the symbolic order. Chicago: The University of Chicago Press.

Hajer, M. A. (2005). Coalitions, practices, and meaning in environmental politics: From acid rain to BSE. In D. Howarth \& J. Torfing (Eds.), Discourse theory in European politics (pp. 297-315). Basingstoke: Palgrave macmillan.

Healey, P. (2007). Urban complexity and spatial strategies. Towards a relational planning for our times. Oxon: Routledge.

Hisschemoller, M., \& Hoppe, R. (1995). Coping with intractable controversies: The case for problem structuring in policy design and analysis. Knowledge and Policy, 8(4), 40-60.

Kurtz, H. E. (2003). Scale frames and counter-scale frames: Constructing the problem of environmental injustice. Political Geography, 22(8), 887-916.

Lakoff, G., \& Johnson, M. (1980). Metaphors we live by. Chicago: The University of Chicago Press.

Laws, D., \& Rein, M. (2003). Reframing practice. In M. A. Hajer \& H. Wagenaar (Eds.), Deliberative Policy Analysis. Understanding governance in the network society. Cambridge University Press.

Lieshout, M. Van, Dewulf, A., Aarts, N., \& Termeer, C. (2011). Do scale frames matter?? Scale frame mismatches in the decision making process of a 'mega farm' in a small Dutch village. Ecology and Society, 16(1).

McAvoy, G. E. (1998). Partisan probing and democratic decisionmaking: Rethinking the Nimby Syndrome. Policy Studies Journal, 26(2), 274-292.

Moran, L., \& Rau, H. (2014). Mapping divergent concepts of sustainability: Lay knowledge, local practices and environmental governance. Local Environment, 9839(October), 1-17.

Nedlund, A., \& Garpenby, P. (2014). Puzzling about problems: The ambiguous search for an evidence-based strategy for handling influx of health technology. Policy Sciences, 47(4), 367-386.

Novy, J., \& Peters, D. (2012). Railway station mega-projects as public controversies: The case of Stuttgart 21. Built Environment, 38(1), 128-145.

Pellizzoni, L. (2011). The politics of facts: Local environmental conflicts and expertise. Environmental Politics, 2o(6), 765-785. 
Rein, M., \& Schon, D. (1993). Reframing policy discourse. In F. Fischer \& J. Forester (Eds.), The argumentative turn in policy analysis and planning (pp. 145-166). London: UCL Press Limited.

Rein, M., \& Schon, D. (1996). Frame-critical policy analysis and frame-reflective policy practice. Knowledge and Policy, 9(1), 85-104.

Schmidt, V. a. (2008). Discursive Institutionalism: The Explanatory Power of Ideas and Discourse. Annual Review of Political Science, 11(1), 303-326.

Schon, D. A., \& Rein, M. (1994). Frame reflection: Toward the resolution of intractrable policy controversies. New York: basic books.

Snow, D. a., Rochford, E. B., Worden, S. K., \& Benford, R. D. (1986). Frame Alignment Processes, Micromobilization, and Movement Participation. American Sociological Review, 51(4), 464.

'Stad speelt met vuur.' (2005, March 18). Het Nieuwsblad/Antwerpen, p. 20.

Stone, D. (2002). Policy paradox. The art of political decision making (Revised Ed.). New York: W.W. Norton \& Company.

Throgmorton, J. a. (2003). Planning as persuasive storytelling in a global-scale web of relationships. Planning Theory, 2(2), 125-151.

van Dijk, T. (2011). Imagining future places: How designs coconstitute what is, and thus influence what will be. Planning Theory, 10, 124-143.

van Eeten, M. J. . (1999). Dialogues of the deaf: Defining new agendas for enviromental deadlocks. Delft: Eburon.

van Herzele, A., \& Aarts, N. (2013). 'My forest, my kingdom'-Selfreferentiality as a strategy in the case of small forest owners coping with government regulations. Policy Sciences, 46(1), 63-81.

van Hulst, M., \& Yanow, D. (2014). From policy 'frames' to 'framing': Theorizing a more dynamic, political approach. The American Review of Public Administration, 1-21.

Verelst, J. (2009a). Een brug te ver? Hoe de Lange Wapper aan het wankelen ging. Antwerpen: Manteau.

Verelst, J. (2009b, October 17). Campagne voeren op enthousiasme en overtuiging. De Morgen, p. 26.

Verelst, J. (2009c, October 19). Patrick Janssens: 'Dit wordt geen boksmatch maar een schaakspel, elke zet is van belang.' De Morgen, p. 2.

Verhoeven, I., \& Duyvendak, J. W. (2015). Enter emotions. Appealing to anxiety and anger in a process of municipal amalgamation. Critical Policy Studies, 0171(October), 1-18.

Vliegenthart, R., \& van Zoonen, L. (2011). Power to the frame: Bringing sociology back to frame analysis. European Journal of Communication, 26(2), 101-115.

Wagenaar, H., \& Hajer, M. (2003). Deliberative policy analysis. New York: Cambridge University Press. 
Wesselink, A., Colebatch, H., \& Pearce, W. (2014). Evidence and policy: Discourses, meanings and practices. Policy Sciences, 47(4), 339-344.

Wolsink, M. (2000). Wind power and the NIMBY-myth: Institutional capacity and the limited significance of public support. Renewable Energy, 21, 49-64. 